\title{
Does Ecotourism Contribute to Sustainable Development? A case at In Banyuwangi
}

\author{
Ni'matul Istiqomah ${ }^{1,{ }^{*}}$, Nur Anita Yunikawati ${ }^{1}$, Emma Yunika Puspasari ${ }^{1}$, and Marzanah A \\ Jabbar $^{2}$ \\ ${ }^{1}$ Faculty of Economic, Universitas Negeri Malang, Indonesia \\ ${ }^{2}$ Faculty of Computer Science, Universiti Putra Malaysia, Malaysia
}

\begin{abstract}
Sustainable development is a very interesting issue to study, with the emergence of sustainable development in 2015 this has become even sturdier. Environmental problems are one of the 17 goals of sustainable development, which is a consideration aspect for country or region in improving social and economic sectors. Ecotourism emerged in an effort to solve various overlapping problems in realizing development. The purpose of this study is to determine the contribution made by ecotourism in realizing sustainable development on Pulau Merah Beach, Banyuwangi. Pulau Merah Beach has applied the concept of ecotourism to support sustainable development goals. This can be seen from the results of interviews, observations and documentation that we have done. Result of collaboration between site managers and business owners makes Pulau Merah Beach visitor's rise, which indirectly increases the amount of revenue for tourism site which was managed by the local government and following with direct impact felt by business owners at the Pulau Merah Beach.
\end{abstract}

\section{Introduction}

As one of the sectors that supports the economy in a country, tourism is one of the sectors that is attractive and has the potential to generate foreign exchange for a country [1]. The growth of the tourism sector continues to increase from year to year [1]. This is supported by the potential of adequate natural and human resources. In addition, tourism is seen as an environmentally friendly sector without causing pollution, but its existence needs to be paid attention to so as not to disturb the balance of nature $[2,3,4]$. An increasingly advanced economy has led to changes in the population structure which will increase competitiveness in meeting needs. From various countries in the world, allocating spending for the tourism sector can create new jobs $[5,6,7]$.

Seeing the many benefits of tourism, especially the contribution to the country's foreign exchange, the tourism sector needs to be further developed because it has the potential to increase from year to year. For that we need an effort to develop potential resources both natural resources and adequate human resources. In tourism development efforts, it is

\footnotetext{
* Corresponding author: nimatul.istiqomah.fe@um.ac.id
} 
necessary to pay attention to environmental aspects, not only pay attention to how to improve the economy and social $[2,8-11]$.

The concept of ecotourism or ecotourism is known as a tourism activity that is more recreational, educational, and conservative. The application of ecotourism does not only take new tourism trips, but includes aspects of education, especially in recognizing culture and nature and preserving nature. Of the 17 countries in the world, Indonesia is one of the countries dubbed Mega Biodiversity along with 2 other countries in Southeast Asia [9, 1214]. Mega biodiversity is a nickname for a country that has unique biodiversity and ecology as well as a high geographical type of structure as an asset for sustainable development. As we know, Indonesia has cultural diversity and potential natural resources and capital in carrying out sustainable development.

In theory, sustainable development involves 3 dimensions, namely Economic, Social and Environmental. [19]. The emergence of the concept of sustainable development certainly has problems that make the dimensions of sustainable development not work as expected. Ecological or environmental problems can be seen from changes in environmental conditions which are getting worse day by day due to soil degradation, air pollution, and the cleanliness of tourist sites. This requires special treatment considering that ecology is one of the dimensions that most supports visual tourism. The world experiences soil degradation of $15 \%$ caused by erosion of water and wind and the use of chemical substances. From these data we can see that the environment has decreased every day in quality and function, therefore ecotourism as a tourism development concept needs special treatment so that the environment is maintained and not damaged by tourism activities. Humans as actors in the ecotourism concept have a contribution to the sustainability of the ecosystem.

Problems in the social dimension include uncontrolled population growth each year. According to estimates, the world's population will increase by 7.8 billion people in 2025 . The high increase in population each year causes new problems, such as poverty levels to lead to malnutrition in every community $[15,8]$. The high level of population poverty also causes gaps between poor and rich countries [16] in addition to disparities between countries, this gap also occurs within the country itself.

In the economic dimension, the main problem is the era of globalization in which since its emergence in 1990, a country is facing conditions where environmental changes and globalization are evident. Globalization is the beginning of the emergence of technology and communication that can assist a country in accessing information to support a country's economy. This condition requires a country to prepare itself to the best of its ability to be side by side with other countries in the field of technology and communication.

Indonesia as one of the countries that has tourism potential is in the spotlight of the world to serve as a tourist destination for foreign tourists. One area with tourism potential that is currently in great demand by foreign tourists is Banyuwangi, East Java. Since almost 10 years, Banyuwangi has started to develop tourism potential because of its natural resources. The beach is one of the potentials of the Banyuwangi area because Banyuwangi is located in the eastern part of the island of Java which has a coastline ranging from northern Banyuwangi which borders the Situbondo Regency to the southern part of Banyuwangi which is famous for its big waves and has the potential to be used as a means of surfing sports.

One of the beaches that have become an icon in Banyuwangi is the Red Island Beach. Red Island is located in the southern area of Banyuwangi Regency so that it has the advantage of big waves and is in demand by surfers. In addition to the potential for large waves, Red Island as one of the beaches in South Banyuwangi has red land and an island that is the hallmark of the Red Island coast.

As one of the tourist locations by utilizing natural potential, in its management it is necessary to pay attention to environmental cleanliness. As one part of ecotourism, the Red Island tourist beach has a responsibility to help protect the environment to carry out 
sustainable development. The coast of Pulau Merah which has the potential to be used as a tourist spot must be considered how it impacts on the sustainability of sustainable development which consists of economic, social, and ecological dimensions. For this reason, this research will discuss how Red Island ecotourism contributes to sustainable development in South Banyuwangi.

\section{Method}

This research method uses a case study qualitative research method. This qualitative research method is a type of research that does not use statistical data in the findings in the field and tries to interpret the meaning of human behavior events according to the perspective of the researcher [17]. Meanwhile, it defines that qualitative research is a scientific activity that is planned, structured, systematic, and has a specific purpose in practical or theoretical terms. Calls qualitative research a gradual process in a cycle and starts from identifying the problem and issue to be researched. Meanwhile, qualitative research is a case study type that involves in-depth data collection involving various sources of information [18].

\section{Result and Discussion}

\subsection{Observation results}

Observations of tourism in Banyuwangi Regency are one of the economic supports for local residents. In developing tourism, we must pay attention to various aspects so as not to damage the existence of the surrounding environment. In 2018, Banyuwangi won the ASEAN Tourism Standard Award as a clean and comfortable tourism category. This of course cannot be separated from the joint effort in creating a clean and comfortable ecotourism area to visit. However, with good cooperation from the community and government, it can stem issues around the environment based on problems around the performance indicators of government agencies. These issues include natural disasters and tsunamis, converted productive land, environmental pollution (soil, air and water), urban sanitation and garbage, and agricultural land [18].

Based on the results of observations made, the Red Island beach as one of the beach icons in South Banyuwangi Regency has an attractive beauty to be visited by both domestic and foreign tourists. The data from the observation also states that the red island beach as a tourist area that uses nature directly helps maintain environmental cleanliness. This can be seen from the efforts of tourism managers, visitors, local residents, and business actors to take part in maintaining a clean environment.

Table 1. The efforts made in order to protect the ecotourism area are as follows.

\begin{tabular}{|c|c|}
\hline Agent & Businesscarried out by \\
\hline The Red Island Manager & $\begin{array}{l}\text { Provide trash cans at tourist sites } \\
\text { - Give boards to keep clean (for example: Throw the trash } \\
\text { in the trash) }\end{array}$ \\
\hline Visitors & $\begin{array}{l}\text { Visitors have the awareness to take part in maintaining } \\
\text { the cleanliness of the environment by throwing trash in } \\
\text { thetrash }\end{array}$ \\
\hline Community & $\begin{array}{l}\text { - The community forms a tourism-aware community that } \\
\text { aims to preserve the environment for thetourist sites }\end{array}$ \\
\hline Business Actor's & - Business actors provide garbage at each of their outlets \\
\hline
\end{tabular}


Based on the table above, it is known that all parties in the Red Island beach tourism area have the awareness to take part in keeping the tourism environment clean. The sensitivity of any advice in developing ecotourism can help in implementing sustainable development. In sustainable development, as written by [19] which consists of economic, social, and environmental conditions, it is depicted in the following figure.

Source: [19]

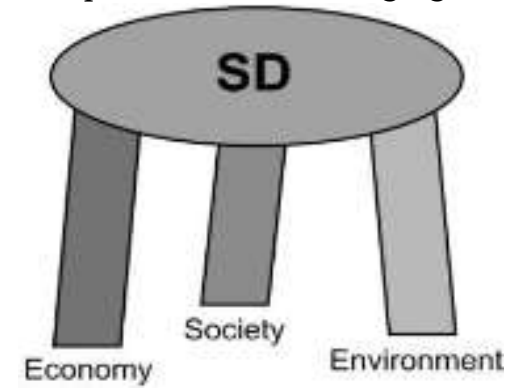

Fig.1. Component of sustainable development

In the picture above, there are 3 dimensions that support sustainable development. In accordance with the theory, this dimension will be examined in the tourist area of the red island. How is the influence of the existence of the Red Island tourist area on these three dimensions. The impact of the awareness of all parties to take part in protecting the ecotourism area seen from the dimensions of sustainable development is as follows.

\subsubsection{Ecological Dimensions}

With the cooperation of residents, business actors, beach managers, and visitors to keep the environment clean, can help ecotourism to be maintained and always clean. Residents of the community around the Red Island as one of the parties that are in direct contact with tourist sites have an important role to play in protecting the environment. According to the data obtained in the field, the community has a very high concern for preserving the environment by establishing a tourism-conscious community whose main purpose is to maintain the cleanliness of the environment of the tourist location. They call this tourism-conscious community the ECO-RANGER community and have a program to clean the beach once a week. The impact of the existence of the Red Island tourist area is still very concerned about the environment, including not polluting the residential area of residents. Sanitation is well organized and has no impact on water sources for local residents.

\subsubsection{Economic dimensions this economic}

Impact is related to the economic life of citizens. The impact of the existence of red island tourism provides opportunities for residents to improve their economic life. The existence of a tourist area opens business opportunities for local residents. The potential along the road to tourist sites is agriculture. The agricultural product that stands out in the area is dragon fruit. With this potential, people will find it easier to market in addition to marketing directly to the fruit market. Ordinary people sell dragon fruit in front of the house to be sold to tourists visiting the red island tour. This certainly makes higher income and makes marketing easier.

In addition, other business opportunities are also seen in the community handicrafts that are marketed to tourists. Another form of business that is carried out by the community is to use the house for the homestay business. Lodging for tourists in the form of homestays is quite helpful for foreign tourists and is in great demand because tourist locations are closer 
and prices are more affordable. From several business opportunities developed by the surrounding community, the economic life of the residents is helped by the additional income.

\subsubsection{Social dimension}

In addition to the impact on the environment and economy, ecotourism affects the social life of the community. One of them is the openness of the community to new customs brought by tourists as long as these customs do not interfere with the customs of the local population. From the results of interviews and seeing conditions during observation, the condition of the community with the existence of this tourist area is getting better because of the impact on the economic sector. In the economic dimension, it is stated that by increasing the economic conditions of the community, it can improve social life, such as the community being able to meet needs and can improve the level of health. In the environmental dimension, the surrounding community has a community called an eco-ranger which aims to keep the Red Island tourist area clean. The formation of the community shows that the social attitudes shown by the community members are still very strong. The social attitude of this community becomes the capital for mutual cooperation, especially in developing the Red Island tourist area.

\subsection{Ecotourism in sustainable development}

The concept of a sustainable economy that has been formulated since 1980 is a response to a development strategy whose main focus is to increase economic growth. Sustainable development is very important in human life and for realizing better environmental conditions according to the agenda of the conference in Brazil in 1992. Sustainable development is development carried out in order to meet human needs without causing damage that affects future generations to meet their needs.

The existence of ecotourism is an important asset to improve the life of the community, especially the surrounding community. Looking at the dimensions related to sustainable development, in the results of research based on observations and interviews, these dimensions are very attached to ecotourism on the red island. This means that the tourist area of the red island has a positive effect on the economic, environmental and social dimensions. This positive influence is a very important asset in supporting sustainable development.

In accordance with the results of the analysis of interviews conducted by researchers, parties who are directly related to the Red Island tourist area are very concerned about the dimensions of sustainable development. Such as maintaining environmental cleanliness, the impact of the tourism area on the economic life of residents and the social life of the community.

The dimensions of a sustainable economy as a model in economic development in this study can be explained in the following explanation.

1. Environmental dimension: The area of the red island which is maintained its sustainability and cleanliness will be a driving factor to attract the attention of visitors so that it will increase attractiveness and encourage the tourism sector and will later encourage economic development

2. Social dimension: people work together to keep the coastal area clean by establishing an association called eco ranger as a form of concern for red island tourism. In addition, an open culture and solidarity between citizens becomes power and capital, especially for the community to support economic development.

3. Economic dimension: economic opportunities are felt by the people around the Red Island coast by selling handicrafts and agricultural products from the surrounding community. 
Thus the economic life of the citizens will improve and economic development will increase.

The community as one of the elements that is in direct contact with the Red Island tourist area has a positive relationship with the existence of the ecotourism area. A positive relationship based on the results of research and observation is that the community as the party who feels the existence of the Red Island tourist area directly benefits both ecologically, socially, and economically. In addition, the existence of the community participates in the development of the Red Island tourist area. This is like the results of research [1] in 3 positive relationships, namely, (1) the community participates in ecotourism development, (2) the community has an insight into ecotourism that is environmentally sound, (3) the community has an environmentally sound attitude in developing ecotourism .

\section{Conclusion}

Based on the research results obtained, it can be concluded that the existence of red island ecotourism pays close attention to studies in the sustainability of development. This can be seen from the results of in-depth interviews and observations from related parties in the existence of the Red Island as a tourist area, namely Perhutani as the manager of the Red Island, the local residents as parties who are around the tourist area and feel the direct impact on the existence of Red Island tourism. Visitors as participants who measure how the state of the tourist location is based on dimensions in sustainable development, and business actors around the Red Island.

\section{References}

1. S. Hayati, "Partisipasi Masyarakat dalam Pengembangan Ekowisata di PangandaranJawa Barat," Forum Geogr., 241, 12 (2010)

2. M. Hultman, A. Kazeminia, and V. Ghasemi, J. Bus. Res., 689, 1854-1861 (2015)

3. H. S. T. Pham and C. N. T. Khanh, "Ecotourism intention: the roles of environmental concern, time perspective and destination image," Tour. Rev., (2020)

4. C. N. Thi Khanh and L. T. Phong, "Impact of environmental belief and nature-based destination image on ecotourism attitude," J. Hosp. Tour. Insights, vol. ahead-of-p, no. ahead-of-print, (2020)

5. E. F. Lambin and P. Meyfroidt, "Global land use change, economic globalization, and the looming land scarcity," Proc. Natl. Acad. Sci. U. S. A., 1089, 3465-3472 (2011)

6. J. I. Pulido-Fernández, L. Andrades-Caldito, and M. Sánchez-Rivero, J. Sustain. Tour., 231, 47-64 (2015)

7. M. K. Bacchus, Comp. Educ., 442, 127-145 (2008)

8. A. H. Bhuiyan, C. Siwar, and S. M. Ismail, Asian Soc. Sci., 99, 11-18 (2013)

9. S. Gössling, P. Peeters, and D. Scott, Third World Q., 295, 873-901 (2008)

10. S. Pratt, Ann. Tour. Res., 52, 148-160 (2015)

11. J. Saarinen and C. M. Rogerson, Tour. Geogr., 161, 23-30 (2014)

12. C. Y. Keong, Int. J. Environ. Sci. Dev., 611, 876-882 (2015)

13. K. von Rintelen, E. Arida, and C. Häuser, "A review of biodiversity-related issues and challenges in megadiverse Indonesia and other Southeast Asian countries," Res. Ideas Outcomes, vol. 3, p. e20860, (2017)

14. G. Baldacchino and I. Novaczek, Isl. Stud. J., 11, 81-108 (2006) 
15. C. D. Butler, Glob. Food Sec., 5, 19-24 (2015)

16. F. Chayandito, "Pembangunan Berkelanjutan, Ekonomi Dan Ekologi, Sustainability Communication Dan Sustainability Reporting," Staf Pengajar pada Fak. Ekon. Univ. Padjadjaran, vol. i, no. 022, pp. 1-12, (1980)

17. Yilmaz, K., Eur. J. Educ., 482, 311-325 (2013)

18. A. P. Dwinugraha, JKMP (Jurnal Kebijak. dan Manaj. Publik), 42, 183 (2017)

19. Hák, Tomás, Bedrich Moldan, and Arthur Lyon Dahl, eds. Sustainability indicators: a scientific assessment. Vol. 67. Island Press, (2012) 